\title{
Productive features of broiler chickens in hot weather: effects of strain and sex
}

\section{Características produtivas de frangos de corte: efeito da linhagem e sexo}

\author{
Dáphinne Cardoso Nagib do Nascimento ${ }^{1 *}$; Leilane Rocha Barros Dourado ${ }^{2}$; \\ Jefferson Costa de Siqueira ${ }^{3}$; Stélio Bezerra Pinheiro de Lima²; Melina da \\ Conceição Macêdo da Silva ${ }^{1}$; Gabriela Gome da Silva'; Nilva Kazue Sakomura ${ }^{4}$; \\ Guilherme José Bolzani de Campos Ferreira ${ }^{2}$; Daniel Biagiotti ${ }^{2}$
}

\begin{abstract}
The objective of the present study was to evaluate the performance of broiler strains (Cobb 500, Ross 308, and Hubbard Flex) in hot weather. Environmental temperatures above thermal comfort trigger responses of the animals to maintain homeothermia, which negatively affects productive performance. A total of 2,160 chicks of both sexes, were distributed in an experimental design that was completely randomized in a factorial arrangement of $3 \times 2$ (strains and sexes) with six replicates of 60 birds each. Feed intake (FI), live weight (LW), weight gain (WG), and feed conversion (FC) were analyzed at periods of 1-7, 1-21, 1-28,1-42, and 1-49 days old. At 42 and 49 days old, the carcass weight (CW), carcass yield (CY), breast yield (BY), thigh yield (TY), and drumstick yield (DY) were analyzed. The strains differed in LW and WG in most periods, especially for Cobb broilers in the pre-start period (1-7 days) and Hubbard broilers in the last two periods (1-42 and 1-49 days). Except for the pre-initial stage, which there was no influence of the strains on FC, the Hubbard broilers showed the best FC, at 1-49 d, similarly to Cobb broilers. Regardless of strain, the males showed superior performance to that of females. At $42 \mathrm{~d}$, the Cobb broilers showed a superior BY to that of the other strains, presenting better TY than did the Ross and Hubbard strains. At $49 \mathrm{~d}$, the Cobb and Ross strains showed the best BY, with the Hubbard strain having the greatest DY. Males showed higher values in cut yields, except in the BY in which females showed better results.
\end{abstract}

Key words: Carcass yield. Genetics. Poultry industry.

\section{Resumo}

Objetivou-se avaliar o desempenho das linhagens de frangos de corte (Cobb 500, Ross 308 e Hubbard Flex) criadas em clima quente. Temperatura ambientais acima do conforto térmico desencadeiam respostas dos animais para a manutenção da homeotermia em detrimento do desempenho produtivo. Foram utilizados 2160 aves, de ambos os sexos, distribuídas em delineamento experimental inteiramente casualizado em esquema fatorial 3 × 2 (linhagem e sexo) com seis repetições de 60 aves cada. Foi avaliado o consumo de ração (CR), ganho de peso (GP), conversão alimentar (CA) e peso vivo (PV),

\footnotetext{
1 Discentes, Universidade Federal do Piauí, UFPI, Teresina/Bom Jesus, PI, Brasil. E-mail: daphinnen@icloud.com; melinacms@ gmail.com; gabigomesbj@outlook.com

2 Profs., UFPI, Bom Jesus, PI, Brasil. E-mail: leilane@ufpi.edu.br; steliolima@ufpi.edu.br; guilherme.ferreira@ufpi.edu.br; biagiotti@ufpi.edu.br

3 Prof., Universidade Federal do Maranhão, UFMA, Chapadinha, MA, Brasil. E-mail: jc.siqueira@ufma.br

${ }^{4}$ Prof $^{\mathrm{a}}$, Universidade Estadual Paulista, UNESP, Jaboticabal, SP, Brasil. E-mail: sakomura@fcav.unesp.br

* Author for correspondence
} 
nos períodos de 1 a 7, 1 a 21, 1 a 28, 1 a 42 e 1 a 49 dias. Aos 42 e 49 dias foram avaliados o peso de carcaça (CAR), rendimento de carcaça $(R C)$, rendimento de peito (RP), rendimento de coxa (RCX) e rendimento de sobrecoxa (RSC). As linhagens diferiram em PV e GP na maioria dos períodos, com destaque para as aves da linhagem Cobb no período pré-inicial (1 a 7 dias) e as aves Hubbard nos dois últimos períodos. Com exceção à fase pré-inicial em que não houve influência das linhagens sobre a $\mathrm{CA}$, as aves Hubbard apresentaram a melhor CA, sendo esta no período de 1 a 49 dias semelhante às aves Cobb. Independente da linhagem, os machos apresentaram desempenho superior em relação às fêmeas. Aos 42 dias as aves Cobb apresentaram RP superior às demais linhagens, sendo o melhor RCX apresentado pelas aves Ross e Hubbard. Aos 49 dias as linhagens Cobb e Ross apresentaram o melhor RP, sendo o maior RSC exibido pela linhagem Hubbard. Os machos tiveram valores superiores nos rendimentos de corte, com exceção no RP em que as fêmeas demonstraram melhores resultados.

Palavras-chave: Avicultura. Linhagens. Rendimento de carcaça.

\section{Introduction}

For decades, those involved in the production chain of broiler chickens have been concerned with the potential for growth and body conformation of poultry, since these characteristics are related to the efficiency and profitability of the poultry sector. Genetic enhancements have resulted in the current broiler chicken strains, which are characterized by faster weight gain and better feed conversion.

Broiler chicken have been successfully commercialized, including live chickens and industrialized products. In Brazil, among the exported products, cuts represent $57.7 \%$ and whole chickens $32.6 \%$, followed by processed products (ABEF, 2016). The diversity of chicken meat supply has driven the present production to develop strains that meet market needs.

Broiler farms comprise different strains, each one presenting unique development and production characteristics. However, for them to realize their performance potential and carcass characteristics, it is necessary to meet the requirements of these animals, since growth and muscular development are influenced by factors such as nutrition, environmental conditions, disease, and housing density (HRUBY et al., 1994).

A limiting factor in the production of broiler chickens in Brazil is the climate, characterized by high ambient temperatures and relative humidity in most regions, and it is necessary to modify the environment to modulate the microclimate inside aviaries, and thus minimize the negative effects of heat stress and decrease the thermal amplitude, which can be as detrimental to birds as heat (DONALD, 1997).

The investment cost in facilities and equipment of ambience is high and may be impractical for some breeders, which consequently may not provide the birds with a controlled thermal environment to maximize their productive potential.

An alternative for producers would be to use more heat resistant strains, and according to Deeb and Cahaner (2001), this resistance can occur naturally in the environment, through breeding strains originating from hot regions or developed by artificial selection.

The performance and carcass characteristics of modern broiler strains maintained within their thermal comfort zones have been described, but this information does not include bird development under different climatic conditions. Where birds are not kept in a suitably controlled environment, they may perform poorly as expected, as they are not in thermal comfort and need to be slaughtered over 42 days of age. Therefore, the objective of the present study was to evaluate the performance and some carcass characteristics of broiler chickens from different strains and sexes, reared under heat stress conditions. 


\section{Materials and Methods}

The experiment was carried out from March 11 to April 29, 2014 in the Poultry Sector of the Technical College of Bom Jesus, Campus Professor Cinobelina Elvas, Federal University of Piauí, located in the municipality of Bom Jesus, PI $\left(09^{\circ}\right.$ $04^{\prime} 26^{\prime \prime} \mathrm{S}, 44^{\circ} 21^{\prime} 32^{\prime \prime} \mathrm{W}$ ), with an average altitude of $277 \mathrm{~m}$. According to the climatic classification of Köppen, the climate of the region falls into the type Aw, considered a tropical zone with dry winters (ALVARES et al., 2013).

For this study, we used 2,160 broilers, half of each sex, from three breeding flocks: Ross 308, Cobb 500, and Hubbard Flex at 42, 37, and 38 weeks of age, respectively. The hatching eggs of the respective strains were purchased from breeder farms located in the states of Ceará, Minas Gerais, and Goiás, and transported in suitable trucks to Teresina, PI, where they were incubated. After reception, the eggs were processed under similar conditions and incubated in a Coopermaq brand hatchery. Sexing through wing feather examination was performed in the hatchery, and the birds were transported and housed approximately 15 hours after hatching.

The birds were weighed and distributed in 362 $\mathrm{m}^{2}$ pens, at a stocking density of $30 \mathrm{birds} / \mathrm{m}^{2}$, in an experimental shed $26 \mathrm{~m}$ long by $8 \mathrm{~m}$ wide, covered with ceramic tiles, with a $3 \mathrm{~m}$ right foot, equipped with movable yellow side curtains to aid in the control of the ambience.

Each pen was fitted with a bell water drinker, cylinder feeder, and 50 watt incandescent bulb for heating. Environmental temperatures and relative humidity (maximum and minimum) were recorded daily using a thermo-hygrometer located in the geometric center of the shed, at the life zone height.

To evaluate the thermal comfort each week, the thermal comfort index enthalpy (comfort index enthalpy - CIE) was determined, based on the following formula:

$$
\begin{aligned}
& \mathrm{H}=6,7+0,243 * \mathrm{Tbs}+\left\{\mathrm{UR} / 100 * 10^{\wedge} 7,5 * \mathrm{Tbs}\right. \\
& / 237,3+\mathrm{Tbs}\}
\end{aligned}
$$

where: $\mathrm{H}$ is the enthalpy ( $\mathrm{kcal} / \mathrm{kg}$ of dry air), $\mathrm{Tbs}$ is the dry bulb temperature $\left({ }^{\circ} \mathrm{C}\right)$, and UR is the relative humidity of the air (\%). The result was multiplied by 4.18 for the unit of measurement $(\mathrm{kJ})$. The enthalpy values are divided into four bands represented by four colors: comfort (green), alert (yellow), critical (orange), and lethal (red) (BARBOSA FILHO et al., 2007). As enthalpy tables were available for data until the sixth week, in the present study, for the evaluation of the thermal comfort in the seventh week, data for enthalpy in the sixth week were used as a reference.

The experimental design was completely randomized in the following factorial arrangement: $3 \times 2$ (strains and sexes), 6 treatments, with six replicates of 60 birds each, and the initial mean weights $( \pm \mathrm{s})$ of the Cobb, Ross and Hubbard strains were: $40.4 \pm 0.03 ; 41.4 \pm 0.10$, and $42.2 \pm 0.12 \mathrm{~g}$ for males, and $40.4 \pm 0.05 ; 39.7 \pm 0.13$, and $41.3 \pm 0.14$ $\mathrm{g}$ for females, respectively.

Diets based on corn and soybean meal were formulated to provide the nutritional requirements of male broilers with superior performance according to the recommendations of Rostagno et al. (2011) (Table 1). The feeding program consisted of four diets according to the age of the birds: $1-7,8-21$, 22-42, and 43-49 d. The animals had free access to water and feed throughout the experimental period.

The light program during the experimental period consisted of $23 \mathrm{~h}$ (natural + artificial light) until d 7, $20 \mathrm{~h}$ (natural + artificial light) from $\mathrm{d} 8$ to 42 , then increased to $22 \mathrm{~h}$ (natural + artificial light) thereafter.

At d 7, 21, 28, 42, and 49, all birds and left over rations from each experimental unit were weighed to evaluate the performance characteristics. The variables analyzed were weight gain (WG), feed intake (FI), feed conversion (FC), and live weight (LW). Mortality was recorded daily, and the subsequent calculation of the average feed intake and feed conversion was determined (SAKOMURA; ROSTAGNO, 2016). 
At d 42 and 49, three birds with body weights close to the average of the pen $( \pm 10 \%)$ were fasted for $6 \mathrm{~h}$ and slaughtered to determine eviscerated carcass weight $(\mathrm{CW})$, carcass yield $(\mathrm{CY})$, breast yield (BY), thigh yield (TY), and drumstick yield
(DY). CY was calculated based on the relationship between CW (without feathers, viscera, feet, head, and neck) and LW. The parts yield was calculated based on the ratio between the cut weight and $\mathrm{CW}$.

Table 1. Ingredients and nutrient composition of the feeds used in the trial.

\begin{tabular}{lcccc}
\hline Ingredient (\%) & $1-7$ & $8-21$ & $22-42$ & $43-49$ \\
\hline Corn & 48.738 & 54.589 & 58.803 & 63.427 \\
Soybean meal & 43.826 & 37.994 & 33.214 & 28.929 \\
Soybean oil & 3.439 & 3.718 & 4.772 & 4.956 \\
Dicalcium phosphate & 1.880 & 1.518 & 1.198 & 0.990 \\
Limestone & 0.779 & 0.814 & 0.732 & 0.653 \\
Salt & 0.452 & 0.482 & 0.452 & 0.432 \\
Mineral and Vitamin Premix $1,2,3,4$ & 0.400 & 0.400 & 0.400 & 0.200 \\
DL-Methionine (99\%) & 0.306 & 0.29 & 0.256 & 0.225 \\
L-Lysine HCL (78,5) & 0.136 & 0.158 & 0.152 & 0.169 \\
L-Threonine (99\%) & 0.044 & 0.037 & 0.021 & 0.019 \\
\hline Total & 100.00 & 100.00 & 100.00 & 100.00 \\
\hline Nutritional composition & & & & \\
\hline ME (kcal/kg) & 2.960 & 3.050 & 3.175 & 3.250 \\
Crude protein (\%) & 24.00 & 22.00 & 20.25 & 18.64 \\
Calcium (\%) & 0.920 & 0.841 & 0.711 & 0.614 \\
Available phosphorus (\%) & 0.470 & 0.401 & 0.332 & 0.286 \\
Sodium (\%) & 0.220 & 0.210 & 0.198 & 0.190 \\
Digestible lysine (\%) & 1.324 & 1.217 & 1.096 & 1.006 \\
Digestible methionine (\%) & 0.615 & 0.579 & 0.525 & 0.477 \\
Digestible methionine + cistyne (\%) & 0.953 & 0.876 & 0.800 & 0.734 \\
Digestible threonine (\%) & 0.861 & 0.791 & 0.712 & 0.654 \\
Digestible tryptophan (\%) & 0.283 & 0.249 & 0.223 & 0.201 \\
Digestible valine (\%) & 1.024 & 0.936 & 0.855 & 0.785 \\
Crude fiber (\%) & 3.437 & 2.958 & 2.778 & 2.631 \\
\hline & & & & \\
\hline
\end{tabular}

Provided per kg of product 1(pre-starter): folic acid - $200 \mathrm{mg}$; biotin-10 mg; chloro hydroxyquinoline -7,500 mg: zn - $17.50 \mathrm{~g}$; vit. A - 1,680,000 UI; vit. B1 - 436.50 mg; vit. B12- 2,400 mg; vit. B2 - 1,200 mg; vit. B6 - 624 mg; vit. D3 - 400,000 UI; vit. E 3,500 UI; vit. K 3 - 360 mg; niacin - 8,399 mg; nicarbazin - 25 g: pantothenic acid - 3,120 mg; choline - 78.10 g; Se - 75 mg; Fe $11.25 \mathrm{~g} ; \mathrm{mn}-18.74 \mathrm{~g}$; $\mathrm{Cu}-1,997 \mathrm{mg}$; I $187 \mathrm{mg}$. 2(starter): folic acid - $199 \mathrm{mg}$; biotin - $10 \mathrm{mg}$; chloro hydroxyquinoline - 7,500 mg; Zn - 17.50 g; vit. A - 1,680,000 UI; vit. B1 - 436.50 mg; vit. B12 - 2,400 mg; vit. B2 - 1,200 mg; vit. B6 - 624 mg; vit. D3 400,000 UI; vit. E - 3500 UI; vit. K 3 - 360 mg; niacin - 8400 mg; monensina -25 g; pantothenic acid - 3119 mg; choline - 80.71 g; Se - 75 mg; Fe 11.25 g; Mn - 18.74 g; Cu - 1996 mg; I - 187.47 mg. 3(grower): folic acid - 162.50 mg; chloro hydroxyquinoline - 7,500 mg: Zn - 17.50 g; vit. A - 1,400,062.50 UI; vit. B1 - 388 mg; vit. B12 - 2,000 mg; vit. B2 - 1,000 mg; vit. B6 - 520 mg; vit. D3 - 360,012 UI; vit. E - $2500 \mathrm{UI}$; vit. K 3 - $300 \mathrm{mg}$; niacin - $7000 \mathrm{mg}$; salinomycin - $16.50 \mathrm{~g}$ : pantothenic acid - $2600 \mathrm{mg}$; choline - 71.59 g; Se - 75 mg; Fe 11.25 g; Mn - 18.74 g; Cu - 1996 mg; I - 187.47 mg. 4(finisher): folic acid - 162.50 mg; zinc oxide - 17.500 mg; Se - 75 mg; vit. A - 140,000 UI; vit. B1 - 388 mg; vit. B12 - 2,000 mg; vit. B2 - 1,000 mg; vit. B6 - 520 mg; vit. D3 - 1,600 UI; vit. E - $2500 \mathrm{mg}$; vit. K 3 - $300 \mathrm{mg}$; Zn - 70 ppm; niacin - 7,000 mg; pantothenic acid - 2,600 mg; choline $71,593.49 \mathrm{mg}$; Fe $11.250 \mathrm{mg}$; Mn - $18.750 \mathrm{mg}$; Cu - $2000 \mathrm{mg}$; I - $187.50 \mathrm{mg}$, antioxidant additive - 25,000 mg; halquinol 7,500 $\mathrm{mg}$; salinomycin - $16,500 \mathrm{mg}$. 
The performance data and carcass characteristics of the birds, referring to the different evaluation periods were initially submitted to normality tests (Cramer-Von Mises) and homoscedasticity (Levene); and once these assumptions were met, they were submitted to analysis of variance according to the statistical model:

$$
\mathrm{Y}_{\mathrm{ij}}(\mathrm{k})=\mu+\operatorname{Strain}_{\mathrm{i}}+\operatorname{Sex}_{\mathrm{j}}+\operatorname{Strain} \times \operatorname{Sex}_{\mathrm{ij}}+\epsilon_{\mathrm{ij}(\mathrm{k})}
$$

where $\mathrm{Y}_{\mathrm{ij}(\mathrm{k})}=\mathrm{FI}, \mathrm{WG}, \mathrm{FC}, \mathrm{LW}, \mathrm{CW}, \mathrm{CY}, \mathrm{BY}, \mathrm{TY}$, and DY of birds of the $\mathrm{i}$-th lineage in the jth sex; $\mu$

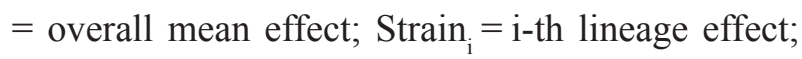
$\mathrm{Sex}_{\mathrm{j}}=\mathrm{jth}$ sex effect; Strain $\times$ Sexij $=$ interaction effect between ith Strain and jth Sex, and $\mathrm{e}_{\mathrm{ij}(\mathrm{k})}=$ experimental error. Subsequently, the means of the analyzed variables were analyzed by the SNK test $(\mathrm{P} \leq 0.05)$, using SAS 9.0 Software (SAS Institute, 2002), through the "GLM" procedure.

\section{Results and Discussion}

The mean, minimum, and maximum temperatures and average relative humidity inside the room during the experimental period were 28.1 $\pm 0.7 ; 22.0 \pm 1.2 ; 34.2 \pm 0.9$; and $73.6 \pm 13.7 \%$, respectively.

The mean and maximum temperatures recorded from the second week of life were above the recommended comfort temperatures in the strains manuals, which indicate temperatures below 26 ${ }^{\circ} \mathrm{C}$ from $18 \mathrm{~d}$ of age (COBB, 2005; HUBBARD, 2007; ROSS, 2012). Minimum periods on most experimental days were observed at about 5:00 and the duration of the mild temperature over a $24 \mathrm{~h}$ period was short. The thermal comfort index enthalpy indicated that the birds were only in thermal comfort in the second week of life (green band), being in the lower and upper alert range (yellow) in the first and third week, respectively. After the third week, the birds were in a critical environment (orange band), which possibly influenced their performance (Table 2).

Table 2. Minimum, maximum, and mean environmental temperature $\left({ }^{\circ} \mathrm{C}\right)$ and relative humidity $(\%)$, standard deviation, and enthalpy comfort index (ECI) weekly, during the period from March 11 to April 29, 2014.

\begin{tabular}{cccccccc}
\hline \multirow{2}{*}{$\begin{array}{c}\text { Period } \\
\text { (days) }\end{array}$} & \multicolumn{3}{c}{ Temperature $\left({ }^{\circ} \mathbf{C}\right)$} & \multicolumn{3}{c}{ Relative humidity (\%) } & IEC (KJ/Kg dry air) \\
\cline { 2 - 8 } & Minimum & Maximum & Mean & Minimum & Maximum & Mean & \\
$\mathbf{1}$ to 7 & 23.3 & 34.2 & $28.75 \pm 0.1$ & 63.0 & 82.1 & $72.5 \pm 0.3$ & 76.81 \\
$\mathbf{8}$ to $\mathbf{1 4}$ & 22.9 & 34.0 & $28.45 \pm 0.1$ & 63.0 & 81.9 & $72.4 \pm 0.4$ & 76.14 \\
$\mathbf{1 5}$ to 21 & 21.1 & 34.9 & $28.00 \pm 0.1$ & 63.1 & 84.1 & $73.6 \pm 0.2$ & 75.48 \\
$\mathbf{2 2}$ to 28 & 22.4 & 34.1 & $28.25 \pm 0.3$ & 65.3 & 84.8 & $75.0 \pm 2.1$ & 76.40 \\
$\mathbf{2 9}$ to 35 & 22.1 & 34.0 & $28.05 \pm 0.3$ & 69.4 & 87.6 & $78.5 \pm 0.8$ & 76.86 \\
$\mathbf{3 6}$ to 42 & 20.5 & 34.4 & $27.45 \pm 0.1$ & 57.1 & 84.8 & $70.9 \pm 2.4$ & 73.66 \\
$\mathbf{4 3}$ to 49 & 21.5 & 33.4 & $27.45 \pm 0.3$ & 48.6 & 87.1 & $67.8 \pm 3.2$ & 72.88 \\
\hline
\end{tabular}

No interactions $(\mathrm{P}>0.05)$ between strains and sex were observed for any of the performance variables evaluated in the pre-initial period (1-7 d) (Table 3), indicating that these factors act independently. It was observed that the strains influenced $(\mathrm{P}<0.05)$ the FI, WG, and LW, whereas the sex influenced $(\mathrm{P}<0.05)$ the WG and LW of the birds, without influence $(\mathrm{P}>0.05)$ of strains or sex on the $\mathrm{FC}$ in the pre-initial period. 
Ross FI was similar to that of the Cobb and Hubbard strains, Cobb consumption being 6.1\% higher than that of Hubbard. Stringuini et al. (2003), when comparing the performance of four broiler strains, did not observe differences in FI between Cobb and Ross strains in the first week of life, corroborating the results of the present study.

The Cobb strain presented a superior WG to that of the Hubbard (8.9\%) and Ross (3.8\%) strains, being $4.9 \%$ superior to that of Hubbard. The effect of strains on the WG of birds at $1-7 \mathrm{~d}$ was found by Abdullah et al. (2010), who verified that the Hubbard Classic strain presented superior WG in relation to Ross and Hubbard JV strains. Similarly to $\mathrm{WG}$, the Cobb strain had a higher LW than the Hubbard (5.3\%) and Ross (3.3\%) strains, which was $2.1 \%$ higher than Hubbard.

Table 3. Mean of feed consumption (FI), weight gain (WG), live weight (LW), and feed conversion (FC) of different strains of males and females at $1-7 \mathrm{~d}$ of age.

\begin{tabular}{|c|c|c|c|c|c|c|c|c|c|}
\hline \multirow{2}{*}{ Variable } & \multirow{2}{*}{$\begin{array}{l}\text { Sex } \\
\text { (S) }\end{array}$} & \multicolumn{3}{|c|}{ Strain $(\mathrm{St})$} & \multirow[b]{2}{*}{ Mean } & \multirow[b]{2}{*}{ CV (\%) } & \multicolumn{3}{|c|}{ Probability } \\
\hline & & Cobb & Ross & Hubbard & & & $\mathrm{St}$ & $\mathrm{S}$ & StxS \\
\hline \multirow{3}{*}{ FI (kg) } & Male & 0.123 & 0.121 & 0.111 & 0.118 & 5.40 & 0.035 & 0.313 & 0.068 \\
\hline & Female & 0.118 & 0.114 & 0.116 & 0.116 & & & & \\
\hline & Mean & $0.121 \mathrm{a}$ & $0.117 \mathrm{ab}$ & $0.114 \mathrm{~b}$ & & & & & \\
\hline \multirow{3}{*}{ WG $(\mathrm{Kg})$} & Male & 0.113 & 0.108 & 0.101 & $0.107 \mathrm{~A}$ & 3.36 & $<0.001$ & 0.006 & 0.109 \\
\hline & Female & 0.107 & 0.104 & 0.101 & $0.104 \mathrm{~B}$ & & & & \\
\hline & Mean & $0.110 \mathrm{a}$ & $0.106 \mathrm{~b}$ & $0.101 \mathrm{c}$ & & & & & \\
\hline \multirow{3}{*}{ LW (kg) } & Male & 0.154 & 0.149 & 0.143 & $0.149 \mathrm{~A}$ & 2.55 & $<0.001$ & $<0.001$ & 0.175 \\
\hline & Female & 0.147 & 0.143 & 0.142 & $0.144 \mathrm{~B}$ & & & & \\
\hline & Mean & $0.151 \mathrm{a}$ & $0.146 b$ & $0.143 \mathrm{c}$ & & & & & \\
\hline \multirow{3}{*}{$\mathrm{FC}$} & Male & 1.089 & 1.121 & 1.099 & 1.103 & 5.77 & 0.629 & 0.455 & 0.411 \\
\hline & Female & 1.107 & 1.102 & 1.148 & 1.119 & & & & \\
\hline & Mean & 1.098 & 1.111 & 1.123 & & & & & \\
\hline
\end{tabular}

Mean followed by a common letter, lowercase in the row and uppercase in the column, do not differ statistically according to the SNK test $(\mathrm{P}>0.05)$.

No effects of strain $(\mathrm{P}>0.05)$ on $\mathrm{FC}$ were observed, despite differences found between FI and strains, showing that in the pre-initial period, Cobb, Ross, and Hubbard birds gained weight with similar efficiencies. Considering the sex, it was observed that males presented higher WG $(2.9 \%)$ and LW $(3.4 \%)$ than that of females, independent of the strain, corroborating with the results of Stringuini et al. (2003) who observed that WG and LW of male broilers of the Ross, Cobb, Avian Farms, and Arbor Acres strains at $1-7 \mathrm{~d}$ were $3.6 \%$ and $2.8 \%$, respectively, higher than that of females.
According to Yassin et al. (2009) the main morphophysiological changes of the digestive, immunological, and thermoregulatory systems occur in the first seven days of life of the birds, which supports the importance of this period for their development. In addition to these factors, the rapid growth of broilers reduces the time of poultry in the field, thus increasing the importance of satisfactory performance in the first week after hatching. However, each strain has a growth potential over a specific period (GOLIOMYTIS et al., 2003; SANTOS et al., 2005); thus, a greater live 
weight or weight gain from one strain to another in the pre-initial period may not translate into greater growth over the life of the bird.

No interactions $(\mathrm{P}>0.05)$ between strain and sex were observed for any of the performance variables evaluated in the period of $1-21 \mathrm{~d}$ (Table 4$)$, in which FI and FC were influenced by the strain $(\mathrm{P}<0.05)$. The performance variables were influenced by sex $(\mathrm{P}<0.05)$, with the exception of FC $(\mathrm{P}>0.05)$.

The birds of the Ross strain had FI that was higher by $1.4 \%$ and $3.4 \%$ than that of the birds of the Cobb and Hubbard strains, respectively, and the FI of the Hubbard birds was $2.0 \%$ lower than that of the Cobb birds. Abdullah et al. (2010) in a study with four strains at 14-21 d, found differences in FI, where the FI of the Ross birds was $12.3 \%$ higher than that of the Hubbard JV birds. The absence of effect of the strains on WG and LW agrees with the results of Farran et al. (2000) when evaluating the performance of three broiler strains (Arbor Acres, Lohman, and Ross) at 1-21 d, finding no strain effect on LW.

The Hubbard birds presented a lower FC than those of the Cobb and Ross strains, which showed similarities. Although there were no differences in WG between the strains at 1-21 d, the lower FI of Hubbard than Cobb and Ross strains, resulted in improved FC, indicating greater growth of Hubbard birds between $\mathrm{d} 7$ and 21, since the birds of the Hubbard strain presented inferior WG and LW in the pre-initial period (1-7 d).

Table 4. Mean of feed consumption (FI), weight gain (WG), live weight (LW), and feed conversion (FC) of different strains of males and females at $1-21 \mathrm{~d}$ of age.

\begin{tabular}{|c|c|c|c|c|c|c|c|c|c|}
\hline \multirow{2}{*}{ Variable } & \multirow{2}{*}{$\begin{array}{l}\text { Sex } \\
\text { (S) }\end{array}$} & \multicolumn{3}{|c|}{ Strain $(\mathrm{St})$} & \multirow[b]{2}{*}{ Mean } & \multirow[b]{2}{*}{ CV (\%) } & \multicolumn{3}{|c|}{ Probability } \\
\hline & & Cobb & Ross & Hubbard & & & $\mathrm{St}$ & S & StxS \\
\hline \multirow{3}{*}{ FI (kg) } & Male & 0.982 & 0.992 & 0.961 & $0.978 \mathrm{~A}$ & 1.32 & $<0.001$ & $<0.001$ & 0.795 \\
\hline & Female & 0.930 & 0.946 & 0.914 & $0.930 \mathrm{~B}$ & & & & \\
\hline & Mean & $0.956 \mathrm{~b}$ & $0.969 \mathrm{a}$ & $0.937 \mathrm{c}$ & & & & & \\
\hline \multirow{3}{*}{ WG (Kg) } & Male & 0.677 & 0.673 & 0.693 & $0.681 \mathrm{~A}$ & 2.92 & 0.238 & $<0.001$ & 0.483 \\
\hline & Female & 0.637 & 0.647 & 0.648 & $0.644 \mathrm{~B}$ & & & & \\
\hline & Mean & 0.657 & 0.660 & 0.670 & & & & & \\
\hline \multirow{3}{*}{ LW(kg) } & Male & 0.718 & 0.715 & 0.735 & $0.722 \mathrm{~A}$ & 2.76 & 0.172 & $<0.001$ & 0.517 \\
\hline & Female & 0.677 & 0.687 & 0.689 & $0.684 \mathrm{~B}$ & & & & \\
\hline & Mean & 0.697 & 0.701 & 0.712 & & & & & \\
\hline \multirow{3}{*}{$\mathrm{FC}$} & Male & 1.451 & 1.474 & 1.388 & 1.438 & 2.49 & $<0.001$ & 0.578 & 0.533 \\
\hline & Female & 1.462 & 1.462 & 1.411 & 1.445 & & & & \\
\hline & Mean & $1.456 \mathrm{a}$ & $1.468 \mathrm{a}$ & $1.399 \mathrm{~b}$ & & & & & \\
\hline
\end{tabular}

Mean followed by a common letter, lowercase in the row and uppercase in the column, do not differ statistically according to the SNK test $(\mathrm{P}>0.05)$.

Analyzing the sex, the males showed a higher FI by $5.2 \%$; WG by $5.7 \%$, and LW by $5.6 \%$ than females; corroborating with the results of Moreira et al. (2004), who also observed a higher FI (8.9\%) and WG $(9.8 \%)$ of the males based on both sexes of three broiler strains (Ross, Cobb, and Hybro).

No interactions $(\mathrm{P}>0.05)$ between strain and sex were observed for any of the performance variables for 1-28 d (Table 5). Similarly to the previous 
period (1-21 days), Ross birds presented the highest FI, which was $3.1 \%$ and $1.9 \%$ higher than that of the Cobb and Hubbard birds, respectively, and there were no differences between Cobb and Hubbard birds. The superiority of the Ross strain did extend to WG and LW, as these were similar to those observed in the Cobb and Hubbard strains. However, despite the similarity in FI of the Cobb and Hubbard birds, the latter presented WG (4.6\%) and LW (4.5\%) higher than the Cobb birds, suggesting a higher WG efficiency of Hubbard birds. It was observed that the birds of the Hubbard strain presented the best FC, $3.3 \%$ higher than Cobb, and $4.3 \%$ higher than Ross birds, with no differences between these strains.

The CR, GP, and PV values of the birds at 1-28 $\mathrm{d}$ were lower than the reference values presented in the guidelines of the lines, with Cobb, Ross, and Hubbard strains having higher PVs by $35 \%, 27 \%$,
$20 \%$, respectively, than birds of the respective lineages in the present study (HUBBARD, 2007; COBB, 2005; ROSS, 2012), and this inferiority may be attributed to the high environmental temperatures during the experimental period, with averages above the comfort range for birds from the second week of life.

Several authors have reported reduced consumption and decreased performance of broiler chickens exposed to heat stress (OLIVEIRA et al., 2006).

The analysis of the performance of the three strains during $1-7,1-21$, and 1-28 d suggested that birds of the Cobb strain showed higher sensitivity to high environmental temperatures than Ross and Hubbard birds, since 1-7 d Cobb birds showed higher WG and LW, and in subsequent periods, the superiority of these variables was not maintained.

Table 5. Mean of feed consumption (FI), weight gain (WG), live weight (LW), and feed conversion (FC) of different strains of males and females at $1-28 \mathrm{~d}$ of age.

\begin{tabular}{|c|c|c|c|c|c|c|c|c|c|}
\hline \multirow{2}{*}{ Variable } & \multirow{2}{*}{$\begin{array}{l}\text { Sex } \\
(\mathrm{S})\end{array}$} & \multicolumn{3}{|c|}{ Strain (St) } & \multirow[b]{2}{*}{ Mean } & \multirow[b]{2}{*}{ CV (\%) } & \multicolumn{3}{|c|}{ Probability } \\
\hline & & Cobb & Ross & Hubbard & & & St & $\mathrm{S}$ & StxS \\
\hline \multirow{3}{*}{ FI (kg) } & Male & 1.643 & 1.695 & 1.669 & $1.669 \mathrm{~A}$ & 2.26 & 0.008 & $<0.001$ & 0.875 \\
\hline & Female & 1.537 & 1.584 & 1.548 & $1.556 \mathrm{~B}$ & & & & \\
\hline & Mean & $1.590 \mathrm{~b}$ & $1.639 \mathrm{a}$ & $1.608 \mathrm{~b}$ & & & & & \\
\hline \multirow{3}{*}{ WG (Kg) } & Male & 1.086 & 1.114 & 1.143 & $1.114 \mathrm{~A}$ & 3.17 & 0.006 & $<0.001$ & 0.797 \\
\hline & Female & 1.002 & 1.017 & 1.040 & $1.020 \mathrm{~B}$ & & & & \\
\hline & Mean & $1.044 \mathrm{~b}$ & $1.066 \mathrm{ab}$ & $1.092 \mathrm{a}$ & & & & & \\
\hline \multirow{3}{*}{$\mathrm{LW}(\mathrm{kg})$} & Male & 1.127 & 1.156 & 1.186 & $1.156 \mathrm{~A}$ & 3.06 & 0.005 & $<0.001$ & 0.765 \\
\hline & Female & 1.042 & 1.057 & 1.082 & $1.060 \mathrm{~B}$ & & & & \\
\hline & Mean & $1.084 \mathrm{~b}$ & $1.106 \mathrm{ab}$ & $1.133 \mathrm{a}$ & & & & & \\
\hline \multirow{3}{*}{$\mathrm{FC}$} & Male & 1.513 & 1.522 & 1.460 & $1.498 \mathrm{~B}$ & 1.95 & $<0.001$ & 0.006 & 0.835 \\
\hline & Female & 1.535 & 1.558 & 1.488 & $1.527 \mathrm{~A}$ & & & & \\
\hline & Mean & $1.524 \mathrm{a}$ & $1.540 \mathrm{a}$ & $1.474 \mathrm{~b}$ & & & & & \\
\hline
\end{tabular}

Mean followed by a common letter, lowercase in the row and uppercase in the column, do not differ statistically according to the SNK test $(\mathrm{P}>0.05)$.

In relation to sex, the same tendency of the previous period was also observed, with males presenting higher FI (6.8\%), WG $(8.5 \%)$, and LW
$(8.3 \%)$ values than that of females, presenting an improvement of $1.9 \%$ in FC. Males presented a higher growth rate and body protein deposition 
(MARCATO et al., 2008), indicating a higher feed intake and lower feed conversion than females.

The comparison of the performance characteristics between the sexes from d 21 is an important tool for the poultry industry. Some markets, such as the Middle East, require a differentiated product obtained by slaughtering poultry aged 25 to $33 \mathrm{~d}$ with an average slaughter weight of 1.450 $\mathrm{kg}$ (SANDI, 2011). In this type of production where the birds are slaughtered younger, females are commonly used, since the abundant production of females of advanced ages is not feasible owing to a greater deposition of body fat in relation to males, and consequently a higher feed conversion. However, the use of male chickens for this type of production can be indicated for hot regions and for sheds with limited technology in ambience control, because with increased age the birds become more sensitive to high ambient temperatures, with a possible decrease in performance and increase in mortality risk, highlighting the importance of studies that assess the effects of strains and sex under hot weather conditions.

During 1-42 d, no interactions $(\mathrm{P}>0.05)$ between strain and sex were observed for any of the performance variables, with strain and sex effects $(\mathrm{P}<0.05)$ for the performance variables evaluated, except for FI that did not have a strain effect $(\mathrm{P}>$ 0.05) (Table 6).

The Hubbard birds showed a higher WG of $8.2 \%$ in relation to the Cobb birds and $5.0 \%$ in relation to the Ross birds, with no differences between the Cobb and Ross strains. However, Moreira et al. (2004) working with the Cobb, Ross, and Hybro strains observed that the Ross birds presented a $3.1 \%$ higher WG than the Cobb birds.

Table 6. Mean of feed consumption (FI), weight gain (WG), live weight (LW), and feed conversion (FC) of different strains of males and females at $1-42 \mathrm{~d}$ of age.

\begin{tabular}{|c|c|c|c|c|c|c|c|c|c|}
\hline \multirow{2}{*}{ Variable } & \multirow{2}{*}{$\begin{array}{l}\text { Sex } \\
(\mathrm{S})\end{array}$} & \multicolumn{3}{|c|}{ Strain $(\mathrm{St})$} & \multirow[b]{2}{*}{ Mean } & \multirow[b]{2}{*}{ CV (\%) } & \multicolumn{3}{|c|}{ Probability } \\
\hline & & Cobb & Ross & Hubbard & & & St & $\mathrm{S}$ & StxS \\
\hline \multirow{3}{*}{ FI (kg) } & Male & 3.364 & 3.441 & 3.382 & $3.396 \mathrm{~A}$ & 4.20 & 0.384 & 0.008 & 0.309 \\
\hline & Female & 3.208 & 3.234 & 3.349 & $3.256 \mathrm{~B}$ & & & & \\
\hline & Mean & 3.286 & 3.337 & 3.365 & & & & & \\
\hline \multirow{3}{*}{ WG $(\mathrm{Kg})$} & Male & 1.904 & 2.012 & 2.081 & $1.999 \mathrm{~A}$ & 4.30 & 0.004 & $<0.001$ & 0.310 \\
\hline & Female & 1.794 & 1.798 & 1.918 & $1.836 \mathrm{~B}$ & & & & \\
\hline & Mean & $1.849 \mathrm{~b}$ & $1.905 \mathrm{~b}$ & $2.000 \mathrm{a}$ & & & & & \\
\hline \multirow{3}{*}{ LW (kg) } & Male & 1.944 & 2.054 & 2.124 & $2.041 \mathrm{~A}$ & 4.21 & 0.004 & $<0.001$ & 0.302 \\
\hline & Female & 1.835 & 1.838 & 1.960 & $1.877 \mathrm{~B}$ & & & & \\
\hline & Mean & $1.890 \mathrm{~b}$ & $1.945 \mathrm{~b}$ & $2.041 \mathrm{a}$ & & & & & \\
\hline \multirow{3}{*}{$\mathrm{FC}$} & Male & 1.769 & 1.711 & 1.626 & $1.702 \mathrm{~B}$ & 4.09 & 0.009 & 0.003 & 0.217 \\
\hline & Female & 1.788 & 1.803 & 1.746 & $1.779 \mathrm{~A}$ & & & & \\
\hline & Mean & $1.779 \mathrm{a}$ & $1.757 \mathrm{a}$ & $1.686 \mathrm{~b}$ & & & & & \\
\hline
\end{tabular}

Mean followed by a common letter, lowercase in the row and uppercase in the column, do not differ statistically according to the SNK test $(\mathrm{P}>0.05)$.

Following the trend of WG, the Hubbard birds presented a higher LW than the Cobb $(8.0 \%)$ and Ross $(4.9 \%)$ birds. Mehaffey et al. (2006) in a comparative study with five broiler strains at 42 $\mathrm{d}$ of age observed similarities between the LW of four genetic groups, with the highest LW strain 
being $5.8 \%$ higher than the average LW of the other strains. The best FC observed during 1-42 d of age was obtained in the birds of the Hubbard line, being $5.2 \%$ and $4.0 \%$ superior to the birds of the Cobb and Ross strains, respectively, and no differences were observed between them. The males presented the highest FI (4.3\%), WG (8.9\%), and LW (8.4\%), and better FC (4.3\%) than that of females. Moreira et al. (2004) in a study with Cobb, Ross, and Hybro strains from 1 to $42 \mathrm{~d}$ of age, also observed higher FI (12.4\%) and WG (17.4\%) in males than that in females, accompanied by an improved FI (4.3\%). In another study, Brewer et al. (2012), comparing the effects of four strains and sex on broiler chickens, observed that the LW of males, regardless of strains, was $13.6 \%$ higher than that of females.

During 1-49 d, no interactions $(\mathrm{P}>0.05)$ between strain and sex were observed for any of the performance variables $(\mathrm{P}<0.05)$ (Table 7). Cobb FI was $5.2 \%$ and $3.9 \%$ lower than that in birds of the Hubbard and Ross strains, respectively, and there were no differences between them. Similarly,
Flemming et al. (1999) studied different broiler strains (Cobb, Hubbard, Ross, Arbor, and Isa) from 1 to $47 \mathrm{~d}$ of age and observed that Cobb birds also had a lower intake than Hubbard (2.1\%) and Ross $(0.2 \%)$ birds, finding no differences between the two latter strains.

The Hubbard birds presented higher WG by $9.3 \%$ and $6.6 \%$ than Cobb and Ross birds, respectively, and there were no differences between these two latter strains. The Hubbard birds presented the highest LW, 9,2\% and 6,5\% superior to that of Cobb and Ross strains, respectively. As observed in the previous periods, the LW of the birds at $49 \mathrm{~d}$ was lower than that recommended by the companies supplying the strains, which according to Cobb, Ross, and Hubbard manuals suggested live weights at 49 days of $3,7863,695$, and $3,076 \mathrm{~kg}$ (HUBBARD, 2007; COBB, 2005; ROSS, 2012), respectively. These differences were probably owing to the sensitivity to high environmental temperatures, as a consequence of the reduction in the FI and decrease in the WG of the birds.

Table 7. Mean of feed consumption (FI), weight gain (WG), live weight (LW), and feed conversion (FC) of different strains of males and females at 1-49 d of age.

\begin{tabular}{|c|c|c|c|c|c|c|c|c|c|}
\hline \multirow{2}{*}{ Variable } & \multirow{2}{*}{$\begin{array}{l}\text { Sex } \\
\text { (S) }\end{array}$} & \multicolumn{3}{|c|}{ Strain $(\mathrm{St})$} & \multirow[b]{2}{*}{ Mean } & \multirow[b]{2}{*}{ CV (\%) } & \multicolumn{3}{|c|}{ Probability } \\
\hline & & Cobb & Ross & Hubbard & & & St & $\mathrm{S}$ & StxS \\
\hline \multirow{3}{*}{ FI (kg) } & Male & 4.143 & 4.348 & 4.339 & $4.276 \mathrm{~A}$ & 3.43 & 0.002 & 0.001 & 0.522 \\
\hline & Female & 3.982 & 4.108 & 4.234 & $4.108 \mathrm{~B}$ & & & & \\
\hline & Mean & $4.062 \mathrm{~b}$ & $4.228 \mathrm{a}$ & $4.286 \mathrm{a}$ & & & & & \\
\hline \multirow{3}{*}{ WG (Kg) } & Male & 2.365 & 2.467 & 2.617 & $2.483 \mathrm{~A}$ & 4.35 & $<0.001$ & $<0.001$ & 0.507 \\
\hline & Female & 2.218 & 2.231 & 2.391 & $2.280 \mathrm{~B}$ & & & & \\
\hline & Mean & $2.291 \mathrm{~b}$ & $2.349 \mathrm{~b}$ & $2.504 a$ & & & & & \\
\hline \multirow{3}{*}{ LW (kg) } & Male & 2.405 & 2.508 & 2.660 & $2.524 \mathrm{~A}$ & 4.27 & $<0.001$ & $<0.001$ & 0.518 \\
\hline & Female & 2.258 & 2.271 & 2.432 & $2.320 \mathrm{~B}$ & & & & \\
\hline & Mean & $2.331 \mathrm{~b}$ & $2.389 \mathrm{~b}$ & $2.546 \mathrm{a}$ & & & & & \\
\hline \multirow{3}{*}{$\mathrm{FC}$} & Male & 1.756 & 1.764 & 1.660 & $1.726 \mathrm{~B}$ & 4.18 & 0.020 & 0.004 & 0.504 \\
\hline & Female & 1.796 & 1.843 & 1.771 & $1.804 \mathrm{~A}$ & & & & \\
\hline & Mean & $1.776 \mathrm{ab}$ & $1.803 a$ & $1.715 b$ & & & & & \\
\hline
\end{tabular}

Mean followed by a common letter, lowercase in the row and uppercase in the column, do not differ statistically according to the SNK test $(\mathrm{P}>0.05)$. 
In regions such as Southeast Piauiense, characterized by high environmental temperatures, producers who do not have air-conditioned sheds need to prolong the duration of the birds in the shed so that they reach the appropriate weight of slaughter; when choosing a certain strain, it is therefore necessary to know the FI and FC specific for each genotype, and not only the WG and LW of the birds.

Despite the similarity in FI between Hubbard and Ross birds, the FC of the Hubbard birds was $4.9 \%$ higher than that of Ross birds, owing to the WG superiority presented by the Hubbard birds. Cobb birds presented a lower FI (5.2\%) and WG $(8.5 \%)$ in relation to the Hubbard birds; however, the FC of the birds of these strains was similar, as well as between the Cobb and Ross strains.

The males presented higher FC (4.9\%), WG $(8.9 \%)$, and LW (8.8\%), and better FC (4.4\%) than that of females, independent of strain. Shin et al. (2012), in a study with different broiler strains of both sexes, also observed superiority in male LW (20.6\%) and a better FC (4.3\%) than that of females, suggesting males would be more suitable for advanced slaughter age, when the goal is to market live birds.

It was observed that none of the carcass traits evaluated at $42 \mathrm{~d}$ presented a relationship $(\mathrm{P}>0.05)$ between strain and sex. However, independent effects $(\mathrm{P}<0.05)$ of strain and sex on $\mathrm{CW}, \mathrm{BY}$, and TY were observed, with no effect $(\mathrm{P}>0.05)$ of these factors on CY and DY (Table 8).

At $42 \mathrm{~d}$ of age, Hubbard birds presented similar CY to Ross birds, being $12.1 \%$ higher than the Cobb strain, and there were no differences between Ross and Cobb birds. However, Abdullah et al. (2010) evaluated the carcass characteristics of the Hubbard, Ross, and Lohman strains at $43 \mathrm{~d}$, and found that the Hubbard line presented a CY $10.0 \%$ higher than that of the Ross strain.

The Cobb birds presented a BY that was higher by $1.14 \%$ and $1.69 \%$ in relation to the Ross and Hubbard birds, respectively. The Ross line presented a $1.55 \%$ higher by than that of the Hubbard strain, with the lowest BY. Scheuermann et al. (2003) evaluated breast muscle growth in different commercial broiler strains, and observed that birds with higher BY had a longer period of muscle deposition, thus increasing the weight and yield of this muscle. The breast is considered an important cut that corresponds to the highest proportion of the broiler carcass, so that small differences in the yields of this cut can be economically important. Therefore, some poultry companies emphasize breast weight and yield in their breeding programs, to provide lineages that specifically address the industrial segments that prioritize BY, emphasizing the importance of evaluating this characteristic in studies with broiler chickens. 
Table 8. Mean of carcass weight (CW), carcass yield (CY), breast yield (BY), thighs yield (TY), and drumstick yield (DW) of different strains of males and females at $42 \mathrm{~d}$ of age.

\begin{tabular}{|c|c|c|c|c|c|c|c|c|c|}
\hline \multirow{2}{*}{ Variable } & \multirow{2}{*}{$\begin{array}{l}\text { Sex } \\
\text { (S) }\end{array}$} & \multicolumn{3}{|c|}{ Strain $(\mathrm{St})$} & \multirow[b]{2}{*}{ Mean } & \multirow[b]{2}{*}{ CV (\%) } & \multicolumn{3}{|c|}{ Probability } \\
\hline & & Cobb & Ross & Hubbard & & & $\mathrm{St}$ & $\mathrm{S}$ & StxS \\
\hline \multirow{3}{*}{$\mathrm{CW}(\mathrm{kg})$} & Male & 1.73 & 1.90 & 1.95 & $1.86 \mathrm{~A}$ & 9.37 & 0.019 & $<0.001$ & 0.764 \\
\hline & Female & 1.55 & 1.62 & 1.72 & $1.63 \mathrm{~B}$ & & & & \\
\hline & Mean & $1.64 \mathrm{~b}$ & $1.76 \mathrm{ab}$ & $1.84 \mathrm{a}$ & & & & & \\
\hline \multirow{3}{*}{$\begin{array}{l}\text { CY } \\
(\%)\end{array}$} & Male & 72.67 & 72.08 & 72.47 & 72.407 & 2.30 & 0.386 & 0.781 & 0.240 \\
\hline & Female & 71.51 & 72.62 & 73.56 & 72.56 & & & & \\
\hline & Mean & 72.09 & 72.35 & 73.01 & & & & & \\
\hline \multirow{3}{*}{$\begin{array}{l}\text { BY } \\
(\%)\end{array}$} & Male & 34.45 & 32.79 & 31.37 & $32.87 \mathrm{~B}$ & 3.68 & $<0.001$ & 0.007 & 0.552 \\
\hline & Female & 35.02 & 34.45 & 32.77 & $34.08 \mathrm{~A}$ & & & & \\
\hline & Mean & $34.76 \mathrm{a}$ & $33.62 b$ & $32.07 \mathrm{c}$ & & & & & \\
\hline \multirow{3}{*}{$\begin{array}{l}\text { TY } \\
(\%)\end{array}$} & Male & 13.20 & 14.09 & 14.61 & $13.97 \mathrm{~A}$ & 3.99 & $<0.001$ & $<0.001$ & 0.062 \\
\hline & Female & 12.47 & 13.13 & 12.84 & $12.81 \mathrm{~B}$ & & & & \\
\hline & Mean & $12.83 b$ & $13.61 \mathrm{a}$ & $13.73 \mathrm{a}$ & & & & & \\
\hline \multirow{3}{*}{$\begin{array}{l}\text { DY } \\
(\%)\end{array}$} & Male & 13.78 & 14.49 & 14.34 & 14.203 & 7.88 & 0.481 & 0.165 & 0.467 \\
\hline & Female & 13.79 & 14.02 & 13.23 & 13.68 & & & & \\
\hline & Mean & 13.78 & 14.26 & 13.78 & & & & & \\
\hline
\end{tabular}

Mean followed by a common letter, lowercase in the row and uppercase in the column, do not differ statistically according to the SNK test $(\mathrm{P}>0.05)$.

Considering TY, it was observed that the Hubbard and Ross birds were superior by 0.9 and $0.8 \%$, respectively, to that of Cobb birds, presenting similar TYs to each other. Marcato et al. (2008), when comparing thigh growth between Cobb and Ross strains up to $56 \mathrm{~d}$ of age, observed that Ross birds presented higher thigh growth rates after $35 \mathrm{~d}$ of age, with a higher weight of this cut at advanced ages.

Males presented higher CY (14.1\%) and TY (1.16\%), but lower BY (1.21\%) values than those of females, concurring with the study of López et al. (2011), in which the females had a BY $0.75 \%$ higher than that of males. At $49 \mathrm{~d}$ of age there was no interaction $(\mathrm{P}>0.05)$ between strains and sex for the carcass traits evaluated, except for $(\mathrm{P}<0.05) \mathrm{TY}$. As at $42 \mathrm{~d}$, the Hubbard strain presented a similar CY to the Ross birds, being $11.6 \%$ superior that of Cobb strain birds, and there were no differences between the Ross and Cobb strains at $49 \mathrm{~d}$. No differences were observed in BY between the birds of the Cobb and Ross strains, which were superior to the Hubbard strain by $1.7 \%$ and $1.6 \%$, respectively. Both strain and sex were found to affect TY; males of Hubbard birds presented the highest TY, which were $1.57 \%$ and $1.83 \%$ higher than that in Cobb and Ross strain males, which did not differ from each other. Among the females, no differences were observed in TY among the lines of the present study. (Table 9). 
Table 9. Mean of carcass weight (CW), carcass yield (CY), breast yield (BY), thighs yield (TY), and drumstick yield (DW) of different strains of males and females at $49 \mathrm{~d}$ of age.

\begin{tabular}{|c|c|c|c|c|c|c|c|c|c|}
\hline \multirow{2}{*}{ Variable } & \multirow{2}{*}{$\begin{array}{l}\text { Sex } \\
\text { (S) }\end{array}$} & \multicolumn{3}{|c|}{ Strain (St) } & \multirow[b]{2}{*}{ Mean } & \multirow[b]{2}{*}{ CV (\%) } & \multicolumn{3}{|c|}{ Probability } \\
\hline & & Cobb & Ross & Hubbard & & & $\mathrm{St}$ & $\mathrm{S}$ & StxS \\
\hline \multirow{3}{*}{$\mathrm{CW}(\mathrm{kg})$} & Male & 1.81 & 1.96 & 1.99 & $1.92 \mathrm{~A}$ & 9.01 & 0.017 & $<0.001$ & 0.331 \\
\hline & Female & 1.63 & 1.62 & 1.85 & $1.70 \mathrm{~B}$ & & & & \\
\hline & Mean & $1.72 \mathrm{~b}$ & $1.79 \mathrm{ab}$ & $1.92 \mathrm{a}$ & & & & & \\
\hline \multirow{3}{*}{$\begin{array}{l}\text { CY } \\
(\%)\end{array}$} & Male & 75.31 & 75.00 & 76.89 & 75.73 & 4.56 & 0.635 & 0.681 & 0.523 \\
\hline & Female & 76.46 & 74.44 & 74.84 & 75.26 & & & & \\
\hline & Mean & 75.90 & 74.72 & 75.86 & & & & & \\
\hline \multirow{3}{*}{$\begin{array}{l}\text { BY } \\
(\%)\end{array}$} & Male & 33.04 & 33.43 & 31.22 & $32.56 \mathrm{~B}$ & 4.14 & 0.008 & 0.003 & 0.487 \\
\hline & Female & 34.81 & 34.15 & 33.22 & $34.06 \mathrm{~A}$ & & & & \\
\hline & Mean & $33.92 \mathrm{a}$ & $33.79 \mathrm{a}$ & $32.22 \mathrm{~b}$ & & & & & \\
\hline \multirow{3}{*}{$\begin{array}{l}\text { TY } \\
(\%)\end{array}$} & Male & $13.18 \mathrm{Ab}$ & $12.92 \mathrm{Ab}$ & $14.75 \mathrm{Aa}$ & 13.62 & 4.86 & $<0.001$ & $<0.001$ & 0.046 \\
\hline & Female & $12.13 \mathrm{Ba}$ & $12.41 \mathrm{Aa}$ & $12.90 \mathrm{Ba}$ & 12.48 & & & & \\
\hline & Mean & 12.65 & 12.67 & 13.83 & & & & & \\
\hline \multirow{3}{*}{$\begin{array}{l}\text { DY } \\
(\%)\end{array}$} & Male & 14.29 & 13.95 & 14.89 & $14.38 \mathrm{~A}$ & 5.86 & 0.050 & 0.002 & 0.961 \\
\hline & Female & 13.39 & 13.09 & 13.85 & 13.44B & & & & \\
\hline & Mean & 13.84ab & $13.52 b$ & $14.37 \mathrm{a}$ & & & & & \\
\hline
\end{tabular}

Mean followed by a common letter, lowercase in the row and uppercase in the column, do not differ statistically according to the SNK test $(\mathrm{P}>0.05)$.

In contrast to the previous age, in which the strains did not influence DY, at $49 \mathrm{~d}$ the DY of Hubbard strain birds was similar to that of the Cobb birds and was $0.85 \%$ higher than that of the Ross birds, with no differences between Ross and Cobb strains. At $49 \mathrm{~d}$, males had higher CY (11.5\%), TY $(1.14 \%)$, and DY $(0.94 \%)$ values than females; however, BY was lower by $1.5 \%$ in females.

In general, the results showed that the Cobb, Ross, and Hubbard strains presented different carcass and performance characteristics, which increase the complexity in choosing between the different genetic groups. Therefore, knowing the way the birds are sold, together with the environmental conditions in which they will be kept, is essential when choosing the strain and the sex.

The birds of the Hubbard strain under conditions of high ambient temperatures showed enhanced performance characteristics, especially in the later periods, than the other strains. Therefore, they could be attractive for commercial producers of live chickens, although they are not yet in the northeastern market for this purpose owing to the white color of their legs. The performance of the Hubbard strain in advanced ages reinforces the discussion that birds with superior performance in the pre-initial phase (1-7 d) do not necessarily reach greater slaughter weight (42 or $49 \mathrm{~d}$ ), as shown in this study. However, the greater weight at slaughter may not be attractive for markets that prioritize cuts, since higher performances do not necessarily translate to higher yields of cut, since Ross and Cobb birds, despite inferior performance, presented higher BY in relation to Hubbard birds, emphasizing the importance of the type of commercialization or production when choosing a certain strain or sex.

It is important to emphasize that the climatic conditions in which the birds were reared in the present study were different from those 
recommended by the strain manuals and thus we observed that the performance of the birds also differed from the reference values found in the manuals.

\section{Conclusion}

Broiler chickens of the different strains studied presented performance data lower than the reference values in their respective manuals when submitted to thermal stress during the growth and finishing period. The Hubbard Flex strain was showed enhanced performance variables than the other strains, and the Ross 308 and Cobb 500 strains showed enhanced cut yields. The males showed better performance and carcass characteristics than females, except for BY.

\section{Acknowledgments}

We would like to thank ASA Alimentos, CIALNE, and Granja Planalto LTDA for the donation of the hatching eggs, and COAVE for the incubation process.

\section{References}

ABDULLAH, A. Y.; AL-BEITAWI, N.; RJOUP, M. M. S.; QUDSIEH, R. I.; ISHMAIS, M. A. A. Growth performance, carcass and meat quality characteristics of different commercial crosses of broiler strains of chicken. Journal Applied Poultry Research, Oxford, v. 47, n. 1, p. 13-21, 2010.

ALVARES, C. A.; STAPE, J. L.; SENTELHAS, P. C.; MORAES, G. J. L. de; SPAROVEK, G. Köppen's climate classification map for Brazil. Meteorologische Zeitschrift, Stuttgart, v. 22, n. 6, p. 711-728, 2013.

ASSOCIAÇÃO BRASILEIRA DOS PRODUTORES E EXPORTADORES DE FRANGO - ABEF. Relatório anual 2016. Brasília, 2016. Disponível em: <http://www. abef.com.br/ubabef/publicações_relatoriosanuais. php>. Acesso em: 12 nov. 2016.

BARBOSA FILHO, J. A. D.; VIEIRA, F. M. C.; GARCIA, D. B.; SILVA, M. A. N.; SILVA, I. J. O. Mudanças e uso das tabelas de entalpia. Piracicaba, 2007. Disponível em: <http://www.nupea.esalq. usp.br>.
Acesso em: 26 dez. 2017.

BREWER, V. B. Big-bird programs: effect of strain, sex, and debone time on meat quality of broilers. Poultry Science, Savoy, v. 91, n. 1, p. 248-254, 2012.

COBB. Guia de manejo para frangos de corte cobb 500. [S.I.: s.n.], 2005. 58 p.

DEEB, N.; CAHANER, A. Genotype-by-environment interaction with broiler genotypes differing in growth rate. 1. The effects of high ambient temperature and naked-neck genotype on lines differing in genetic background. Poultry Science, Savoy, v. 80, n. 6, p. 695702, 2001.

DONALD, J. Environmental control options under different climatic conditions. World Poultry, Elsevier, v. 14, n. 11, p. 22- 23, 1997.

FARRAN, T. M.; KHALIL, R. F.; UWAYJAN, M. G.; ASHKARIAN, V. M. Performance and carcass quality of commercial broiler strains. Journal Applied Poultry Research, Oxford, v. 9, n. 2, p. 252-257, 2000.

FLEMMING, J. S.; JANZEN, S. A.; ENDO, M. A. Teste com linhagens comerciais de frango de corte - avaliação dos parâmetros zootécnicos. Archieves Veterinary Science, Curitiba, v. 4, n. 1, p. 57-59, 1999.

GOLIOMYTIS, M.; PANOPOULOU, E.; ROGDAKIS, E. Growth curves for body weight and major component parts, feed consumption, and mortality of male broiler chickens raised to maturity. Poultry Science, Savoy, v. 82, n. 7, p. 1061-1068, 2003.

HRUBY, M.; HAMRE, M. L.; COON, C. Growth modeling as a tool for predicting amino acid requirements of broilers. Journal of Applied Poultry Research, Oxford, v. 3, n. 4, p. 403-415, 1994.

HUBBARD FLEX. Performance summary. Quintin: Hubbard, 2007. 4 p.

LÓPEZ, K. P.; SCHILLING M. W.; CORZO, A. Broiler genetic strain and sex effects on meat characteristics. Poultry Science, Savoy, v. 90, n. 5, p. 1105-1111, 2011.

MARCATO, S. M.; SAKOMURA, N. K.; MUNARI, D. P.; FERNANDES, J. B. K.; KAWAUCHI, Í. M.; BONATO, M. A. Growth and body nutrient deposition of two broiler commercial genetic lines. Brazilian Journal of Poultry Science/Revista Brasileira de Ciência Avícola, Campinas, v. 10, n. 2, p. 117-123, 2008.

MEHAFFEY, J. M.; PRADHAN, S. P.; MEULLENET, J. F.; EMMERT, J. L.; MCKEE, S. R.; OWENS, C. M. Meat quality evaluation of minimally aged broiler breast fillets from five commercial genetic strains. Poultry Science, Savoy, v. 85, n. 5, p. 902-908, 2006. 
MOREIRA, J.; MENDES, A. A.; ROÇA, R. O.; GARCIA, E. A.; NAAS, I. A.; GARCIA, R. G.; PAZ, I. C. L. A. Efeito da densidade populacional sobre desempenho, rendimento de carcaça e qualidade da carne em frangos de corte de diferentes linhagens comerciais. Revista Brasileira de Zootecnia, Viçosa, v. 33, n. 6, p. 1506-1519, 2004.

OLIVEIRA, R. F. M.; DONZELE, J. L.; ABREU, M. L. T.; FERREIRA, R. T.; VAZ, R. G. M. V.; CELLA, P.S. Efeitos da temperatura e da umidade relativa sobre $\mathrm{O}$ desempenho e o rendimento de cortes nobres de frangos de corte de 1 a 49 dias de idade. Revista Brasileira de Zootecnia, Viçosa, v. 35, n. 3, p. 797-803, 2006.

ROSS. Frango. Objetivos de desempenho. Huntsville: Aviagen, 2012. 16 p.

ROSTAGNO, H. S.; ALBINO, L. F. T.; DONZELE, J. L.; GOMES, P. C.; OLIVEIRA, R. F. M.; LOPES, D. C.; FERREIRA, A. S.; BARRETO, S. L. T. EUCLIDES, F. R. Tabelas brasileiras para aves e suínos: composição de alimentos e exigências nutricionais. 3. ed. Viçosa, MG: Departamento de Zootecnia, Universidade Federal de Viçosa, 2011. 252 p.

SAKOMURA, N. K.; ROSTAGNO, H. S. Métodos de pesquisa em nutrição de monogástricos. 2. ed. Jaboticabal: Funep, 2016. 262 p.
SANDI, A. J. Consolidação do Custo do avicultor para a produção de frango de corte "Griller" em Santa Catarina, ano 2011. Concórdia: Embrapa Suínos e Aves, 2011. 495 (Comunicado Técnico Embrapa).

SANTOS, A.; SAKOMURA, N. K.; FREITAS, E. R.; FORTES, C. M. L. S.; CARRILHO, E. N. V. M.; FERNANDES, J. B. K. Estudos do crescimento, desempenho, rendimento de carcaça e qualidade de carne de três linhagens de frangos de corte. Revista Brasileira Zootecnia, Viçosa, v. 34, n. 5, p. 1589-1598, 2005.

SCHEUERMANN, G. N.; BILGILI, S. F.; HESS, J. B.; MULVANEY, D. R. Breast muscle development in commercial broiler Chickens. Poultry Science, Savoy, v. 82, n. 10, p. 1648-1658, 2003.

STATISTICAL ANALYSIS SYSTEM INSTITUTE SAS Institute. Statistical Analysis System for Windows. v. 90. Cary: SAS Institute, 2002.

STRINGUINI, J. H.; LABOISSIÉRE, M.; MURAMATSU, K.; LEANDRO, N. S. M.; CAFÉ, M. B. Avaliação do desempenho e rendimento de carcaça de quatro linhagens de frangos de corte criadas em Goiás. Revista Brasileira de Zootecnia, Viçosa, v. 32, n. 1, p. 183-190, 2003.

YASSIN, H.; VELTHUIS, A. G. J.; BOERJAN, M.; VAN RIEL, J. Field study on broilers' first - week mortality. Poultry Science, Savoy, v. 88, n. 4, p. 798-804, 2009. 
